\title{
THE RECONTEXTUALIZATION OF THE SPIRITUAL VALUE FASTING IN IMPROVING THE BODY'S IMMUNE SYSTEM DURING THE COVID 19 PANDEMIC
}

\author{
Shifa Nisrina Sujana ${ }^{1 *}$, Sabiq Muhammad U1-Haq ${ }^{2}$ \\ ${ }^{1}$ Garut University, West Java, Indonesia, e-mail: n.shifas123@gmail.com \\ ${ }^{2} M A$ Persis Tarogong Garut,West Java, Indonesia, e-mail:sabiqsiulhaquee@gmail.com \\ *Corresponding Authors
}

\begin{abstract}
(c) (i) (2)
(C2021 by the authors. Submitted for possible open access publication under the terms and conditions of the Creative Commons Attribution-ShareAlike 4.0 International License-(CC-BY-SA) (https://creativecommons.org/licenses/by-sa/4.0/) doi) DOI : http://dx.doi.org/10.30983/it.v5i2.4967

Submission: 7 November $2021 \quad$ Revised: 13 December $2021 \quad$ Published: 31 December 2021
\end{abstract}

\begin{abstract}
This study focuses on how the process of fasting in Ramadan and sunnah (Monday-Thursday) among Muslims can improve the immune system of practitioners and even affect their social life to practice sunnah fasting. The Corona Virus pandemic, which is still a global problem, not only has an impact on people's social lives, but also encourages many Muslim communities to look for alternative solutions to maintain the vitality of their bodies. Fasting is one method that is currently becoming a trend in society because it is believed by the community that this method is able to ward off various kinds of diseases, especially as exemplified by Prophet Muhammad and Prophet Musa. This study uses a qualitative descriptive method that analyzes the practice of fasting in Ramadan and Monday-Thursday and its implications for the immune system. Data collection techniques used in this study were social observation and interviews with fasting practitioners. The analysis technique consists of data collection, data reduction, data presentation, and drawing conclusions and levers. The results of this study indicate that fasting performed by Muslims is not only able to improve the quality of health but also mental condition because they have a sense of optimism about their condition, especially in the face of a pandemic.
\end{abstract}

Keywords: Fasting, Body immunity, Covid-19 pandemic.

\begin{abstract}
Abstrak
Penelitian ini berfokus pada bagaimana proses puasa Ramadhan dan sunah (Senin-Kamis) di kalangan umat Islam mampu meningkatkan sistem kekebalan para praktisi dan babkan mempengarubi kebidupan sosial mereka untuk menjalankan puasa sunnah. Pandemi Virus Corona yang masib menjadi masalah global tidak hanya berdampak pada kehidupan sosial masyarakat, tetapi juga mendorong banyak. komunitas Muslim untuk mencari solusi alternatif demi menjaga vitalitas tubub mereka. Puasa merupakan salah satu metode yang saat ini menjadi tren masyarakat karena diyakini masyarakat bahwa metode ini mampu menangkal berbagai macam penyakit, terutama seperti yang dicontobkan Nabi Mubammad dan Nabi Musa. Penelitian ini menggunakan metode deskriptif kualitatifyang menganalisis praktik. puasa Ramadhan dan Senin-Kamis serta implikasinya terbadap sistem kekebalan tubuh. Teknik pengumpulan data yang digunakan dalam penelitian ini adalah observasi sosial dan wawancara dengan praktisi puasa. Teknik analisis terdiri atas pengumpulan data, reduksi data, penyajian data, serta penarikan kesimpulan dan verifikasi. Hasil penelitian ini menunjuk.kan bahwa puasa yang dilakukan oleh umat Islam tidak hanya mampu meningkatkan kualitas kesehatan tetapi juga kondisi mental karena mereka memiliki rasa optimisme terhadap kondisi mereka, terutama dalam menghadapi pandemi.
\end{abstract}

Kata Kunci: Puasa, Imunitas, Pandemic covid-19.

\section{Background}

The number of chronic disease sufferers in Indonesia has increased every year. This case is exacerbated by the deteriorating condition of world health which is currently facing the Covid19 Pandemic which has claimed millions of lives in more than a year. ${ }^{1}$ The disease not only affects

1 Gloria Setyvani Putri, "Angka Kematian Akibat Penyakit Tidak Menular di Indonesia Melonjak,” Kompas, 2020. 
adults, but also children and toddlers. ${ }^{2}$ This is not only caused by the consumption of less nutritious foods and irregular eating patterns, which lead to a decline in health conditions, ${ }^{3}$ but also caused by viruses that continue to multiply (mutate) and damage the immune system, making them susceptible to various diseases. ${ }^{4}$ If it continues, the weak immune system causes chronic diseases to develop massively in the community and cause several social problems such as loss of productivity of human resources and social dysfunction or often referred to as social exclusion. $^{5}$

To overcome this problem, people often use various methods of treatment such as hospital treatment and non-conventional treatment such as alternative medicine with traditional massage methods, for example Thai massage ${ }^{6}$ and the use of Chinese herbal medicine. ${ }^{7}$ The main reason why many people do this is that they want a healthy and fit body condition. Even some people also do activities such as dieting and fasting to reduce the amount of food intake so that the nutrients digested in the body are more balanced compared to irregular meal times.

In the perspective of the Abrahamic religion (Judaism, Christianity, and Islam), the practice of fasting has been listed in the holy book and carried out in the form of obligatory and sunnah worship for its adherents. In addition to being intended for worship, fasting is also carried out in order to overcome immune problems, especially in a global health crisis like the one we are experiencing nowadays. ${ }^{8}$ Adherents of the

2 Admin, "Penyakit-Penyakit Kronis Yang Dapat Menyerang di Usia Muda," Axa, 2020.

3 Kevin Adrian, "14 Tanda Tubuh Kamu Kekurangan Gizi," Alodokter, 2019.

4 Admin, "Tentang Mutasi D614G Hingga Varian Baru Corona Dari Inggris,” Detik.com, 2020.

5 Adrian Bonner, Social Exclusion And The Way Out An Individual and Community Response to Human Social Dysfunction (West Sussex: John Wiley \& Sons Ltd, 2006), 3.

${ }^{6}$ Pierce Salguero and David Roylance, Encyclopedia of Thai Massage (Scotland: Findhorn Press, 2004), 17.

7 Volked Scheid et al., Chinese Herbal Medicine Formulas \& Strategies, 2nd ed. (Seattle: Eastland Press, 2009), 17.
Abrahamic religion believe that fasting provides many physical and spiritual benefits. The practice of fasting is still ongoing today, but sometimes it has a different meaning. This is due to the development of the times which indirectly affect their understanding and even their theological beliefs.

In ancient times when the practice of animism and dynamism took place, fasting was associated with purification of the soul as well as preparation for the use of certain transcendental powers. In this context, the practice of fasting is believed to be the last ritual that forms an accelerator of spirits and magical powers among ritual practitioners. ${ }^{9}$ Over time, fasting is transformed into an expression of obedience in religious behavior. ${ }^{10}$ In addition, fasting is also believed to be a form of atonement for past sins and gratitude for all the gifts from God, especially in Christianity and Islam. ${ }^{11}$

The practice of fasting in Islam consists of several types, but in this article the author will focus on the obligatory fasting that is carried out during the month of Ramadan before Eid al-Fitr (Hijriyah calendar) and the sunnah fasting which is carried out every Monday and Thursday. This search aims to analyze the practice of fasting carried out by religious adherents and their correlation with public health, especially in terms of body immunity. The author also focuses on looking at how the practice of fasting by Muslims can affect people's lifestyles, especially those who have chronic diseases and weak immune systems

8 Mike Bickle and Dana Candler, The Rewards of Fasting: Experiencing the Power and Affections of God (Missouri: Forerunner Books, 2005), 129.

9 Graham Harvey, The Handbook of Contemporary Animism (Oxon: Routledge, 2014), 425, https://doi.org/10.5860/choice.51-5670.

${ }^{10}$ Lorraine V. Aragon, Fields of the Lord (Hawai'i: Hawai'i Press, 2000), 283.

11 Paul F. Bradshaw and Maxwell E. Johnson, The Origins of Feasts, Fasts, and Seasons (London: Society for Promoting Christian Knowledge, 2011), 33.

The Recontextualization of the Spiritual... 
and how fasting can improve people's quality of life.

Until now there have been several studies conducted by several researchers related to fasting in Islam. The first article is narrated by Abdul Munib (2019) which discusses the fasting tradition carried out by Muslims in Karduluk Village, Sumenep. How do the people of Karduluk consider fasting only an obligation whose motivation is to avoid punishment and get a reward from Allah SWT, and some view fasting as a spiritual need for humans to stay in touch with their God. ${ }^{12}$ Another researcher, Anita Widiasari Partini (2021), explained that fasting provides many benefits for Muslims both from a religious and scientific perspective. ${ }^{13}$ In the Islamic perspective, fasting can be used as an expiation of sins, forming good morals, as selfprotection from immoral acts, and others. Meanwhile, from a scientific perspective, fasting can relieve and treat diseases such as gastric disease, diabetes, and obesity.

These studies focus more on the transformation of ritual changes that occur in Islam, but topics that focus on the implementation of fasting in people's lives and its social impact are still lacking. Moreover, the discussion related to the reproduction of religious values carried out by teachers in terms of selfcontrol over food consumption is still theological, meaning that it does not enter into socio-anthropological discussions. Therefore, this paper will focus on the implications of religious teachings related to fasting rituals and interpretations of adherents of Islam in terms of fasting practices and their relation to strengthening the immune system in society, so that they can contribute to understanding the recontextualization of Islamic fasting teachings which have not been discussed comprehensively.

The author also focuses this scientific work on the contextualization of worship that is

12 Daniel Winchester, "A Hunger for God: Embodied Metaphor as Cultural Cognition in Action," Social Forces 95, no. 2 (2016): 585.

Shifa Nisrina Sujana, etc.

114 present in Islamic religious teachings during the pandemic, so that they can explore information related to the relevance of Islamic fasting teachings to the conditions of fasting practitioners. To facilitate this research, the formulation of the problem was translated into several research questions including, asking what the participants felt when fasting, positive changes in the participants' bodies when fasting routinely, emotional changes when fasting, and the relationship between fasting and the improvement of the immune system and as well as the severity of the person exposed to Covid19.

This study uses a qualitative descriptive method with observation techniques on practitioners of Ramadan fasting and sunnah fasting Monday-Thursday. Interviews were conducted on several people who are fasting between the ages of $18-50$ years, to gather information about the drivers of their activity and how fasting can affect their lives, especially in the area of physical and mental health. The data from the observation interviews were processed by reducing and drawing conclusions based on the concept of questions that focused on the effect of fasting on the immune system and lifestyle of the participants. The author also uses some of the literature in this study to strengthen the findings obtained.

\section{The Spiritual Value of Fasting on the Performance of the Body's Organs}

While fasting, Muslims strictly control the timing and intake of their food, from dawn to sunset. This activity does not only affect food intake, but also the pattern of daily activities while fasting. According to one informant, fasting is a way for their families, especially children, to adopt a healthy lifestyle by not consuming the food they usually buy while playing during the day, and replacing it with eating together when

13 Fereidoun Azizi, "Islamic Fasting and Health," Annals of Nutrition and Metabolism 56, no. 4 (2010): 273, https://doi.org/10.1159/000295848. 
breaking their fast with healthier home-cooked meals. ${ }^{14}$ Likewise with fasting, Muslims believe that they apply a good diet recommended by the Prophet Muhammad, because fasting gives rest to the organs of the body to restore the body's performance to the fullest. This belief is also reinforced by data from previous research which states that the digestive system can rest first from the continuous work of digestion ${ }^{15}$ and result in the reduced time needed to overcome some symptoms of indigestion, as well as the process of repairing damaged cells and tissue systems. ${ }^{16}$ So that by fasting, the digestive system can rest for 14 hours. ${ }^{17}$ The results of this study strengthen a study which states that the digestive system can rest for 6 (six) hours. ${ }^{18}$

There are several other benefits of fasting that are believed by adherents of Islam, especially those related to the body such as maximizing the metabolic system. Fasting can make the digestive system work substantially in processing food and can change the microbial community in the intestine. ${ }^{19}$ The intake of nutrients, especially carbohydrates, can change the shape of the microbial community that lives in the intestine, because these microbes consume sugar derived from carbohydrates. In addition, the gut microbiome and metabolic health are affected by the schedule of food consumption. Another benefit is to reduce inflammation in the digestive tract because when people fast there is no food $2021\}$.

14 Hasan, (fasting practitioner) Interview, \{26 Juli

${ }^{15}$ Mufaizin Mufaizin, "Kearifan Syariat dan Hikmah dalam Puasa," Al-Insyirob: Jurnal Studi Keislaman 2, no. 1 (2018): https://doi.org/10.35309/alinsyiroh.v2i1.3335.

16 Soesanti Harini Hartono, "Puasa Ramadan, Kesempatan Bersihkan Saluran Pencernaan Dari Virus dan Bakteri," Health.grid.id, 2020.

${ }^{17}$ Hartono, "Puasa Ramadan, Kesempatan...".

18 Moh Andi Hidayat, "Nilai-Nilai Pendidikan Islam dalam Ibadah Puasa Ramadan" (Jember: IAIN Jember Press, 2016), 52.

${ }^{19}$ Fitri Elizabrth Br Hasibuan and Beivy Jonathan Kolondam, "Interaksi Antara Mikrobiota Usus dan Sistem Kekebalan Tubuh Manusia," Jurnal Ilmiah Sains 17, no. 1 (2017): 35 .

Shifa Nisrina Sujana, etc. that passes through the digestive tract except water. $^{20}$ This not only stops the flow of compounds that could potentially cause inflammation, but can reduce inflammation further. During fasting, the activity of antiinflammatory cytokines (proteins made by cells) is greater than the activity of pro-inflammatory cytokines, so the body becomes antiinflammatory. ${ }^{21}$

Another benefit of fasting is that it reduces stress on the digestive system, because fasting reduces oxidative stress through genes. ${ }^{22}$ Oxidative stress through genes is damage that occurs in cells due to exposure to toxicity. Proteins, lipids, and DNA cells are the cells that are completely affected and disturbed. Reducing stress on digestion can prevent a leaky gut, which is one of the factors that prevent a person from fasting. ${ }^{23}$ By minimizing exposure to toxicity and reducing inflammation, the body's cells positively have room for regeneration which can increase the body's immunity for defense against various types of germs or viruses, one of which is the Covid-19 virus. ${ }^{24}$

Not only that, fasting can also cleanse toxins and substances that have accumulated in the digestive tract, kidneys, and other organs due to preservatives, dyes, artificial sweeteners, carcinogenic substances that cause cancer, cigarette smoke and other materials that have

20 Lelya Hilda, "Puasa dalam Kajian Islam dan Kesehatan," Hikmah: Jurnal Pendidikan Islam 8, no. 1 (2014): 58; Verury Verona Handayani, "Apa Yang Terjadi Pada Saluran Cerna Saat Puasa?,” Halodoc, 2021.

${ }^{21}$ Genesis, "Ternyata Berpuasa Dapat Menyehatkan Usus, Lho!," Genesis.com, 2021, https://enesis.com/id/artikel/ternyata-berpuasa-dapatmenyehatkan-usus-lho/.

22 Pipih Muhopilah, Witrin Gamayanti, and Elisa Kurniadewi, "Hubungan Kualitas Puasa dan Kebahagiaan Santri Pondok Pesantren Al-Ihsan," Jurnal Psikologi Islam dan Budaya 1, no. 1 (2018): 55, https://doi.org/10.15575/jpib.v1i1.2071.

${ }^{23}$ Redaksi Halodoc, "Terbukti Menyehatkan, Ini 4 Manfaat Puasa Untuk Pencernaan,” Halodoc, 2017.

${ }^{24}$ Firdaus Anwar, "Puasa Bisa Picu Regenerasi SelSel Kekebalan Tubuh,” Detik health, 2017.

The Recontextualization of the Spiritual... 
accumulated over the years. ${ }^{25}$ Fasting activity also means resting the digestive tract. On a macro scale, fasting will have an impact on body cells, where biochemical reactions take place, one of which is carbohydrates and proteins. ${ }^{26}$ When the digestive system rests, the energy needed is taken from carbohydrate reserves and fat deposits. In a balanced physical and psychological situation, biochemical reactions run more smoothly, directed, and harmless. ${ }^{27}$

This source of literature regarding the benefits of fasting is in line with the results obtained from interviews, where there are people who feel their body conditions are getting fitter because there is time to stop eating harmful foods. Besides that, digestion also becomes smooth, and can also reduce the risk of contracting Covid-19 by not interacting much with outsiders, one of which is food or snack vendors. ${ }^{28}$

\section{The Spiritual Value of Fasting in Boosting the Immune System}

In the previous discussion, aspects related to the digestive system and its relationship to the body's immune system or the body's defense against disease have been discussed. ${ }^{29}$ The immune system is strongly influenced by the quality and quantity of a person's nutritional intake. In the case of Covid-19, individuals who are malnourished will be very vulnerable to being infected with Covid-19. Vice versa, people with good nutrition and adequate energy needs can

\footnotetext{
25 Hilda, "Puasa dalam Kajian Islam dan Kesehatan."

26 Wahyudi, "Empat Dimensi Kesehatan dalam Berpuasa," Bimaispamekasan.net, 2020.

${ }^{27}$ Khoirul Muslimin, "Puasa Menyehatkan Jiwa

Raga," Radarkudus.jawapos.com, 2018.

${ }^{28}$ Enong, (Participant) Interview, \{25 Juli 2021\}.

29 Ahmad Syarif Walakula, "Puasa Menurut Perspektif Biologi dalam Kajian Metabolisme Tubuh dan Hubungannya dengan Kesehatan" (Ambon: IAIN Ambon Press, 2019), 71.

30 Ika, "Puasa Mampu Tingkatkan Imunitas," Ugm.ac.id, 2020, https://www.ugm.ac.id/id/berita/19334puasa-mampu-tingkatkan-imunitas.

31 Ardi Teristi Hardi, "Booster Imun Tubuh Dengan Berpuasa," M.mediaindonesia.com, 2020.
}

increase the potential of the body's ability to resist and destroy the Covid-19 virus. ${ }^{30}$ This is because fasting activities can also stimulate the body to produce new white blood cells that can be used to maintain immunity. ${ }^{31}$ This is the basis for the entire immune system to regenerate. Because basically, during fasting, the body is forced to use the stored sugar and fat in the body for activities, thus facilitating the recycling process of old and damaged immune cells, such as old white blood cells being replaced by new white blood cells. ${ }^{32}$ After the immune system regenerates, it will have a good impact on the body, namely the body will be stronger in warding off various bacterial and viral infections and other diseases. ${ }^{33}$ As stated by a source named Salman "I feel that my body is getting sick less and is more fit so I am not afraid of being exposed to Covid-19". ${ }^{34}$

In a study conducted by the University of Southern California, it was found that fasting is also one way that can be used to reduce the side effects of chemotherapy in cancer patients. ${ }^{35}$ This is because the condition of hunger when a person fasts can encourage the body to save energy by recycling the necessary immune cells. ${ }^{36}$ In trials conducted, for 6 months a number of cancer patients were asked to fast regularly for two and four days. From these experiments, the results were obtained that it can reduce the PKA (Protein kinase A) enzyme or enzymes and

32 Desi, "Menjaga Daya Tahan Tubuh Saat Puasa," Ugm.ac.id, 2021, https://www.ugm.ac.id/id/berita/20998menjaga-daya-tahan-tubuh-saat-puasa.

33 Qurri Hafidhatul, "Gambaran Hitung Jenis Leukosit Pada Siswa SMA Ar-Raudhah Yang Melakukan Puasa Senin Kamis" (Madura: STIKes Ngudia Husada Madura Press, 2020), 21.

34 Salman, (Participant) Interview, \{29 Juli 2021\}.

35 C Lee and V D Longo, "Fasting vs Dietary Restriction in Cellular Protection and Cancer Treatment: From Model Organisms to Patients," Oncogene 30 (2011): 3305-16, https://doi.org/10.1038/onc.2011.91.

36 Ariska Puspita Anggraini, "Riset Buktikan Puasa Dapat Tingkatkan Daya Tahan Tubuh," Health.kompas.com, 2020.

The Recontextualization of the Spiritual... 
hormones that cause aging which usually increases the risk of cancer and tumor growth. ${ }^{37}$

\section{The Benefits of Fasting on Healthy Lifestyle Changes}

Fasting can also affect a person's mental health, because fasting can help a person control his emotions. Controlling emotions will have positive effects such as being able to calm the mind, and increase intelligence which causes the body not to respond quickly to negative things. ${ }^{38}$ In addition to having an impact on physical and mental health, fasting can also affect daily activities. When fasting, people will often lose energy to do various activities. ${ }^{39}$ This happens because of a lack of food intake and lack of sleep because they have to eat sahur in the morning. ${ }^{40}$ In overcoming this problem, fasting practitioners often make healthy eating patterns. ${ }^{41}$ Because in this case, food intake is not only in terms of the type of food, but a good diet is also considered. ${ }^{42}$

A regular diet is very important for the health of the body, while an irregular diet can cause disturbances in the digestive system which can lead to diseases such as gastritis. Problems in the digestive system should not be underestimated. ${ }^{43}$ According to Zayyin (one of the informants), views that digestive problems are the mother of various serious diseases, "if you

${ }^{37}$ Ayu Isti Prabandari, "4 Manfaat Puasa Bagi Sistem Imun, Ampuh Tingkatkan Kekebalan Tubuh," M.merdeka.com, 2020.

38 Saeid Golbidi et al., "Health Benefits of Fasting and Caloric Restriction," Springer 17 (2017), https://doi.org/https://doi.org/10.1007/s11892-0170951-7.

${ }^{39}$ Krisna Octavianus Dwiputra, "Badan Lemas Saat Puasa, Mungkin Anda Mengalami Kondisi Ini," www.klikdokter.com, 2019.

40 Siwi Nur Wakhidah, "9 Penyebab Badan Lemas Tak Bertenaga, Sering Mengantuk dan Gemeteran," www.merdeka.com, 2019.

41 Wildan Rahman Muharam, Imas Damayanti, and Yati Ruhayati, "Hubungan Antara Pola Makan dan Status Gizi Dengan Tingkat Kebugaran Atlet Dayung," Jurnal of Sport Science and Education, 2019.

${ }^{42}$ Nurwijayanti, "Pola Makan, Kebiasaan Sarapan dan Status Gizi Berhubungan dengan Prestasi Belajar Siswa SMK di Kota Kediri," Jurnal Care 6, no. 1 (2018): 55.

43 Sri Hartati, Wasisto Utomo, and Jumaini, "Hubungan Pola Makan Dengan Resiko Gastritis Pada want to be healthy, you must take care of digestion because it is the source of disease and fasting can treat it". ${ }^{44}$ This is following some literature which states that complications caused by digestive disorders can cause serious problems, both in the affected organs and in the surrounding organs. Some of these complications are gastrointestinal bleeding, anemia (lack of red blood cells), dehydration, osteoporosis (bone loss), fistula (abnormal passage) between the intestine and bladder, splenomegaly (enlarged spleen), nutritional deficiencies, narrowing of the esophagus. $^{45}$

In Islam, the habit of applying a good diet is applied in one of the pillars of Islam that must be practiced, namely fasting. During fasting, the diet is arranged in two times, namely at Sahur and iftar (before sunrise and after sunset). Eating patterns at Sahur and Iftar is often done to maximize the intake of proper nutrition, in order to meet energy needs during fasting. ${ }^{46}$

In addition, the practice of fasting is also believed to be a form of self-acclimatization to the values of discipline by doing anything at the right time ${ }^{47} \mathrm{By}$ fasting, a person will avoid things that can invalidate the fast, and be diligent in increasing good activities and good deeds. ${ }^{48}$ According to one of the informants, Yelis, of the

Mahasiswa Yang Menjalani Sistem KBK," Jurnal Online

Mahasiswan Program Studi Ilmu Keperawatan 1, no. 2 (2014).

44 Zayyin, (Participant) Interview, \{25 Juli 2021\}.

${ }^{45}$ Handre Putra, Yusri Dianne Jurnalis, and Yorva

Sayoeti, "Tatalaksana Medikamentosa Pada Penyakit Saluran Cerna," Jurnal Kesehatan Andalas 8, no. 2 (2019): 407, https://doi.org/10.25077/jka.v8i2.1019; Tjin Willy, "Gangguan Pencernaan," alodokter.com, 2019, https://www.alodokter.com/gangguan-pencernaan.

${ }^{46} \mathrm{Ika}$, "Tetap Bugar Selama Puasa Dengan Menjaga Pola Makan Sehat," Ugm.ac.id, 2018; Hanjaya Siaputra et al., "Pola Perilaku Sehat Pra Lansia dalam Mengkonsumsi Makanan Sehari-Hari di Maumere Studio," Jurnal Hospitality dan Manajemen Jasa 3, no. 1 (2015): 131-40.

${ }^{47}$ Saifullah, "Konsep Pembentukan Karakter Siddiq dan Amanah Pada Anak Melalui Pembiasaan Puasa Sunat," Jurnal Mudarrisuna 7, no. 1 (2017): 77-102.

${ }^{48}$ Haris Riadi, "Kesalehan Sosial Sebagai Parameter Kesalehan Keberislaman (Ikhtiar Baru dalam Menggagas Mempraktekkan Tauhid Sosial)," An-Nida' Jurnal Pemikiran Islam 39, no. 1 (2014): 49-58, http://ejournal.uinsuska.ac.id/index.php/Anida/article/view/864. 
opinion that "activities carried out by fasting people tend to turn to useful activities". ${ }^{49}$ Even ordinary activities such as self-restraint and patience, exercise to sleeping activities, are believed to provide more value in terms of the reward obtained from Allah, because they are carried out while fasting. Moreover, famous preachers such as Gus Baha ${ }^{50}$ and Ali Zainal Abidin $^{51}$ often explain the virtues of normal activities carried out during fasting.

On the other hand, fasting can affect mental health, based on the results of an interview with Abdurahman "fasting can regulate or control emotions, by controlling emotions will have a positive influence such as the mind and heart become calmer". ${ }^{52}$

From a medical point of view, resting during the day has many positive values, such as filling the brain's energy needs in the form of blood and oxygen. ${ }^{53}$ This process is often referred to as the Natural Healing Mechanism (the process of forming damaged body cells). It also provides time to rest or maintain the balance of metabolism and body biochemistry. ${ }^{54}$ Resting during the day while fasting can increase energy, because by fasting the pattern of daily activities changes slightly, causing the body's performance to match the body's ability while fasting. By habituation of these activities, it will indirectly have an impact on self-control habits when fasting to do healthy activities and also consume

\footnotetext{
${ }^{49}$ Yelis, (Participant) Interview, $\{27$ Juli 2021\}.

${ }^{50}$ Lufaefi, "Alasan Mengapa Tidurnya Orang Puasa Itu Ibadah, Begini Menurut Gus Baha," Akurat.com, 2021.

51 M. Ali Zainal Abidin, "Maksud Hadits "Tidur Orang Berpuasa Adalah Ibadah,” Nuonline, 2020. $2021\}$

52Abdurahman, (Participant) Interview, \{28 Juli

53 Sukadiyanto, "Peranan Latihan Olahraga

Terhadap Perkembangan Otak," Jurnal Cakrawala Pendidikan 23, no. 1 (2004): 99-118.

54 M Fahruddin Ghozali and Ade Eviyanti, "Sistem Pakar Diagnosa Dini Penyakit Leukimia Dengan Metode 'Certainty Factor,"' Kinetik 1, no. 3 (2016): 135, https://doi.org/10.22219/kinetik.v1i3.122.

55 Ika Sartika, Ellis Endang Nikmawati, and Ai Mahmudatussa'adah, "Pengetahuan Dan Keterampilan
}

healthy food so that the body gets enough nutritious food needs.

The choice of food consumption is one of the health factors in accordance with the diversification of the chosen food. ${ }^{55}$ Diversification of food consumption is a process of choosing food not only depending on one type of food, but also have a variety of choices from various food ingredients. ${ }^{56}$ In other words, this concept is not only limited to staple foods. ${ }^{57}$

The issue of a balanced diet has been alluded to in the teachings or habits of the prophet Muhammad in Islam. As stated in the Qur'an and Sunnah which are the guidelines for the life of Muslims, ${ }^{58}$ it is explained the limitations in the diet for Muslims, one of which is fasting.

There is no prohibition for financially capable believers, to enjoy delicious food and drinks, but still have to comply with the provisions set by the syara' such as good, lawful and according to a proper size and not excessive. The interpretation of the Ministry of Religion says, therefore at the end of verse 88 of AlMaidah, Allah reminds the believers to be careful and fear God in matters of food, drink and other pleasures. ${ }^{59}$ In enjoying halal and tayyib food and drinks, it should not be excessive, or extravagant, as Allah says in Q.S. Al-A'raf verse 31.

On the other hand, when the stomach is full, a lot of blood is channeled to carry out the digestive process, so that a lot of blood flow is concentrated in the stomach and intestines,

Pemilihan Makanan Sehari-Hari Mahasiswa Program Studi Pendidikan Tata Busana," Media Pendidikan, Giži Dan Kuliner 3, no. 1 (2014): 70.

56 Rita Hanafie, "Peran Pokok Lokal Tradisional dalam Diversifikasi Pangan," Journal of Social and Agricultural Economics 4, no. 2 (2010): 6.

57 Kelik Putranto and Ahmad Taofik, "Pola Diversifikasi Konsumsi Pangan Masyarakat Adat Kampung Cireundeun Kota Cimahi Jawa Barat," Jurnal ISTEK 8, no. 1 (2014): 161.

58 Erwin Jusuf Thaib, “Al-Qur'an dan As-Sunnah Sebagai Sumber Inspirasi Etos Kerja Islami," Jurnal Dakwah Tabligh 15, no. 1 (2014): 2.

59 Huzaemah Tahido Yanggo, "Makanan dan Minuman dalam Perspektif Hukum Islam," Tabkim 9, no. 2 (2013): 8 .

The Recontextualization of the Spiritual... 
which results in reduced blood supply to the brain and causes the brain to be deprived of oxygen, energy, and food, make nerve cells unable to work properly to transmit signals. ${ }^{60}$

When it comes to the phenomenon of today's pandemic, fasting is increasingly being recommended by many parties, such as puritans and traditionalists who believe that a strong and healthy body can ward off various viruses and bacteria from multiplying in the body. In this regard, the researcher also conducted interviews with several Muslim practitioners who fast Monday-Thursday and Ramadan. They assume that the values in practicing fasting not only provide psychological benefits, but also health that can reduce the possibility of them contracting the Corona virus.

The slogan that emerged among the people in the West Java area was "maintain immunity and faith to live safely", which was later promoted by the government, which has strengthened social beliefs that religious values and religious activities such as fasting can fortify themselves from various health problems. This invitation has been continuously promoted by the government since the Corona virus has plagued the people of West Java until now. Moreover, the government has carried out various consolidations with religious leaders to carry out various ways of handling and controlling the spread of the Corona virus, especially in places of worship and followers of the Abrahamic religion, one of which is Islam.

\section{The Spiritual Value of Fasting Rituals as an Effort to Minimize the Severity of Being Infected with Covid-19}

In addition to the assumption that fasting provides psychological benefits and reduces the possibility of contracting the Covid-19 virus, it is also believed to reduce the impact or symptoms

${ }^{60}$ Nimas Mita Etika, "Kenapa Kebanyakan Makan Bikin Otak Jadi 'Lemot'?," Hellosehat.com, 2021.

${ }^{61}$ Ray Faradillahisari Nursofwa et al., "Penanganan Pelayanan Kesehatan di Masa Pandemi Covid-19 dalam Perspektif Hukum Kesehatan," Jurnal Inicio Legis 1, no. 1 (2020): 3, https://doi.org/10.21107/il.v1i1.8822.

Shifa Nisrina Sujana, etc. of co-morbidities if a person contracts the virus. Infectious diseases that are suffered by many can be prevented or reduced in severity through efforts to improve nutrition and lifestyle as previously described, because they can increase the body's immunity. This is also related to a person's immune system, in which the body's resistance to infection with the COVID-19 virus will cause several symptoms.

Symptoms that arise from each person tend to be different, because the body's response to this infection is influenced by the strength of each person's immune system. Some of the symptoms that are present in people who have been infected with the COVID-19 virus will usually appear within 2-14 days after the virus enters the body. ${ }^{61}$ In people who have a strong immune system, this virus will be defeated, so the symptoms that arise include mild or moderate symptoms and will disappear or heal on their own without further treatment, such as low-grade fever, cough, fatigue, loss of sense of taste or smell, ${ }^{62}$ can also be accompanied by severe shortness of breath, Chronic Fatigue syndrome (chronic fatigue syndrome), myalgia (muscle pain), gastrointestinal symptoms such as diarrhea and other respiratory symptoms. People with mild symptoms are usually only advised to recover and self-isolate at home. As in the case of one of the informants who felt the benefits of a healthy lifestyle and diligently fasted both voluntary and obligatory so that they have a good immune system, "I did not feel any severe symptoms after being exposed to Covid-19 and tended to be able to carry out activities as usual because of only mild symptoms such as mild cough."63

In contrast to people who have a weak immune system, the body will tend to be overwhelmed by the symptoms or body reactions

62 Nurul Aeni, "Pandemi COVID-19: Dampak Kesehatan, Ekonomi, \& Sosial," Jurnal Litbang: Media Informasi Penelitian, Pengembangan dan IPTEK 17, no. 1 (2021): 19, https://doi.org/10.33658/jl.v17i1.249.

${ }^{63}$ Rika, (Participant) Interview, $\{8$ Juli 2021\}. 
caused by this viral infection, because basically antibodies are proportional to the severity of symptoms. ${ }^{64}$ Severe symptoms such as high fever, shortness of breath, difficulty speaking or moving, chest pain, Acute Respiratory Distress Syndrome (ARDS) or severe respiratory distress, septic shock, uncorrected metabolic acidosis and bleeding or coagulation system dysfunction within a few days, to organ damage. ${ }^{65}$ This condition is also at risk in the elderly (elderly), people with high mobility, and who have previous comorbidities, such as diabetes, heart disease, hypertension, cancer, asthma or HIV (Human Immunodeficiency Virus) ${ }^{66}$

Most patients with mild and moderate symptoms of Covid infection have a good prognosis, while a small proportion of people with severe symptoms can be in a critical condition or even die. This condition when the body has a congenital disease or is in a low immune condition is what causes the high fatality rate of COVID-19. Because of the vigilance against the worst possibility of contracting this virus, the community is aggressively doing everything so that they and their families can survive in this pandemic condition, including inviting family members to be diligent in fasting and getting closer to God.

\section{Conclusion}

The contextualization of fasting among Muslims during the Covid-19 period not only strengthens the religious values of its adherents, but also increases the belief that they receive various medical benefits. Participants experienced an increase in their immune power and felt the changes that occurred when fasting so that they were motivated to carry out various other religious teachings because they believed

64 InfoSehat FKUI, "Berkaca Dari Kasus India, Tetap Jaga Imunitas Tubuh Walau Sudah Vaksin Covid19," fk.ui.ac.id, 2021, https:/ / fk.ui.ac.id/infosehat/berkacadari-kasus-india-tetap-jaga-imunitas-tubuh-walau-sudahvaksin-covid-19/.

65 Y Yuliana, "Corona Virus Diseases (Covid-19): Sebuah Tinjauan Literatur," Wellness And Healthy Magazine that this could save them from the Covid-19 pandemic.

Furthermore, the phenomenon of the widespread implementation of religious teachings which are believed to improve body health has become a new trend in society, especially during the COVID-19 pandemic because people are starting to become interested in the integration of religious and scientific values. This is also an illustration of the methods of community members to be able to continue to survive in a crisis situation by using various methods including religious values so that religious values are starting to be seen as having various aspects other than theological interests.

\section{References}

Abidin, M. Ali Zainal. "Maksud Hadits "Tidur Orang Berpuasa Adalah Ibadah." Nuonline, 2020.

Admin. "Penyakit-Penyakit Kronis yang Dapat Menyerang di Usia Muda." Axa, 2020.

"Tentang Mutasi D614G Hingga Varian Baru Corona dari Inggris." Detik.com, 2020.

Adrian, Kevin. "14 Tanda Tubuh Kamu Kekurangan Gizi.” Alodokter, 2019.

Aeni, Nurul. "Pandemi COVID-19: Dampak Kesehatan, Ekonomi, \& Sosial." Jurnal Litbang: Media Informasi Penelitian, Pengembangan dan IPTEK 17, no. 1 (2021): 17-34.

https://doi.org/10.33658/jl.v17i1.249.

Anggraini, Ariska Puspita. "Riset Buktikan Puasa Dapat Tingkatkan Daya Tahan Tubuh." Health.kompas.com, 2020.

Anwar, Firdaus. "Puasa Bisa Picu Regenerasi SelSel Kekebalan Tubuh.” Detik health, 2017.

Aragon, Lorraine V. Fields of the Lord. Hawai'i:

2, no. 1 (2020): https://doi.org/10.30604/well.95212020.

66 Adityo Susilo et al., "Coronavirus Disease 2019: Tinjauan Literatur Terkini," Jurnal Penyakit Dalam Indonesia 7, no. 1 (2020): 58, https://doi.org/10.7454/jpdi.v7i1.415.

The Recontextualization of the Spiritual... 
Hawai'i Press, 2000.

Azizi, Fereidoun. "Islamic Fasting and Health." Annals of Nutrition and Metabolism 56, no. 4 (2010): 273-82. https://doi.org/10.1159/000295848.

Bickle, Mike, and Dana Candler. The Rewwards of Fasting: Experiencing the Power and Affections of God. Missouri: Forerunner Books, 2005.

Bonner, Adrian. Social Exclusion and The Way Out An Individual and Community Response to Human Social Dysfunction. West Sussex: John Wiley \& Sons Ltd, 2006.

Bradshaw, Paul F., and Maxwell E. Johnson. The Origins of Feasts, Fasts, and Seasons. London: Society for Promoting Christian Knowledge, 2011.

Desi. "Menjaga Daya Tahan Tubuh Saat Puasa." Ugm.ac.id, 2021. https://www.ugm.ac.id/id/berita/20998menjaga-daya-tahan-tubuh-saat-puasa.

Dwiputra, Krisna Octavianus. "Badan Lemas Saat Puasa, Mungkin Anda Mengalami Kondisi Ini." www.klikdokter.com, 2019.

enesis. "Ternyata Berpuasa Dapat Menyehatkan Usus, Lho!” Genesis.com, 2021. https://enesis.com/id/artikel/ternyataberpuasa-dapat-menyehatkan-usus-lho/.

Etika, Nimas Mita. "Kenapa Kebanyakan Makan Bikin Otak Jadi 'Lemot'?" Hellosehat.com, 2021.

Ghozali, M Fahruddin, and Ade Eviyanti. "Sistem Pakar Diagnosa Dini Penyakit Leukimia dengan Metode 'Certainty Factor.” Kinetik 1, no. 3 (2016): 135. https://doi.org/10.22219/kinetik.v1i3.122.

Golbidi, Saeid, Andreas Daiber, Bato Korac, Huige Li, M. Faadiel Essop, and Ismail Laher. "Health Benefits of Fasting and Caloric Restriction." Springer 17 (2017). https://doi.org/https://doi.org/10.1007/s 11892-017-0951-7.

Hafidhatul, Qurri. "Gambaran Hitung Jenis Leukosit Pada Siswa SMA Ar-Raudhah Yang Melakukan Puasa Senin Kamis." Madura: STIKes Ngudia Husada Madura Press, 2020.
Halodoc, Redaksi. “Terbukti Menyehatkan, Ini 4 Manfaat Puasa untuk Pencernaan.” Halodoc, 2017.

Hanafie, Rita. "Peran Pokok Lokal Tradisional dalam Diversifikasi Pangan." Journal of Social and Agricultural Economics 4, no. 2 (2010): 17.

Handayani, Verury Verona. "Apa yang Terjadi pada Saluran Cerna Saat Puasa?” Halodoc, 2021.

Hardi, Ardi Teristi. "Booster Imun Tubuh dengan Berpuasa." M.mediaindonesia.com, 2020 .

Hartati, Sri, Wasisto Utomo, and Jumaini. "Hubungan Pola Makan dengan Resiko Gastritis Pada Mahasiswa yang Menjalani Sistem KBK." Jurnal Online Mahasiswan Program Studi Ilmu Keperawatan 1, no. 2 (2014).

Hartono, Soesanti Harini. "Puasa Ramadan, Kesempatan Bersihkan Saluran Pencernaan dari Virus dan Bakteri." Health.grid.id, 2020.

Harvey, Graham. The Handbook of Contemporary Animism. Oxon: Routledge, 2014. https://doi.org/10.5860/choice.51-5670.

Hasibuan, Fitri Elizabrth Br, and Beivy Jonathan Kolondam. "Interaksi antara Mikrobiota Usus dan Sistem Kekebalan Tubuh Manusia." Jurnal Ilmiah Sains 17, no. 1 (2017).

Hidayat, Moh Andi. "Nilai-Nilai Pendidikan Islam dalam Ibadah Puasa Ramadan." Jember: IAIN Jember Press, 2016.

Hilda, Lelya. "Puasa dalam Kajian Islam dan Kesehatan." Hikmah: Jurnal Pendidikan Islam 8, no. 1 (2014): 53-62.

Ika. "Puasa Mampu Tingkatkan Imunitas." Ugm.ac.id, 2020. https://www.ugm.ac.id/id/berita/19334puasa-mampu-tingkatkan-imunitas.

—. "Tetap Bugar Selama Puasa dengan Menjaga Pola Makan Sehat." Ugm.ac.id, 2018.

InfoSehat FKUI. "Berkaca dari Kasus India, Tetap Jaga Imunitas Tubuh Walau Sudah Vaksin Covid-19.” Fk.ui.ac.id, 2021. 
https://fk.ui.ac.id/infosehat/berkaca-darikasus-india-tetap-jaga-imunitas-tubuhwalau-sudah-vaksin-covid-19/.

Lee, C, and V D Longo. "Fasting vs Dietary Restriction in Cellular Protection and Cancer Treatment: From Model Organisms to Patients." Oncogene 30 (2011): 3305-16. https://doi.org/10.1038/onc.2011.91.

Lufaefi. "Alasan Mengapa Tidurnya Orang Puasa Itu Ibadah, Begini Menurut Gus Baha." Akurat.co, 2021.

Mufaizin, Mufaizin. "Kearifan Syariat dan Hikmah dalam Puasa." Al-Insyiroh: Jurnal Studi Keislaman 2, no. 1 (2018): 103-27. https://doi.org/10.35309/alinsyiroh.v2i1.3 335.

Muharam, Wildan Rahman, Imas Damayanti, and Yati Ruhayati. "Hubungan antara Pola Makan dan Status Gizi dengan Tingkat Kebugaran Atlet Dayung." Jurnal of Sport Science and Education, 2019.

Muhopilah, Pipih, Witrin Gamayanti, and Elisa Kurniadewi. "Hubungan Kualitas Puasa dan Kebahagiaan Santri Pondok Pesantren AlIhsan." Jurnal Psikologi Islam dan Budaya 1, no. 1 (2018): 53-66. https://doi.org/10.15575/jpib.v1i1.2071.

Muslimin, Khoirul. "Puasa Menyehatkan Jiwa Raga.” Radarkudus.jawapos.com, 2018.

Nursofwa, Ray Faradillahisari, Moch Halim Sukur, Bayu Kurniadi Kurniadi, and . Haris. "Penanganan Pelayanan Kesehatan di Masa Pandemi Covid-19 dalam Perspektif Hukum Kesehatan.” Jurnal Inicio Legis 1, no. 1 (2020): 1-17. https://doi.org/10.21107/il.v1i1.8822.

Nurwijayanti. "Pola Makan, Kebiasaan Sarapan dan Status Gizi Berhubungan dengan Prestasi Belajar Siswa SMK di Kota Kediri." Jurnal Care 6, no. 1 (2018): 54-63.

Prabandari, Ayu Isti. "4 Manfaat Puasa bagi Sistem Imun, Ampuh Tingkatkan Kekebalan Tubuh.” M.merdeka.com, 2020.

Putra, Handre, Yusri Dianne Jurnalis, and Yorva Sayoeti. "Tatalaksana Medikamentosa pada Penyakit Saluran Cerna." Jurnal Kesehatan Andalas 8, no. 2 (2019): 407-18. https://doi.org/10.25077/jka.v8i2.1019.

Putranto, Kelik, and Ahmad Taofik. "Pola Diversifikasi Konsumsi Pangan Masyarakat Adat Kampung Cireundeun Kota Cimahi Jawa Barat." Jurnal ISTEK 8, no. 1 (2014): 159-81.

Putri, Gloria Setyvani. “Angka Kematian Akibat Penyakit Tidak Menular di Indonesia Melonjak.” Kompas, 2020.

Riadi, Haris. "Kesalehan Sosial Sebagai Parameter Kesalehan Keberislaman (Ikhtiar Baru dalam Menggagas Mempraktekkan Tauhid Sosial)." An-Nida' Jumal Pemikiran Islam 39, no. 1 (2014): 49-58. http://ejournal.uin-

suska.ac.id/index.php/Anida/article/view/ 864.

Saifullah. "Konsep Pembentukan Karakter Siddiq dan Amanah pada Anak Melalui Pembiasaan Puasa Sunat." Jurnal Mudarrisuna 7, no. 1 (2017): 77-102.

Salguero, Pierce, and David Roylance. Encyclopedia of Thai Massage. Scotland: Findhorn Press, 2004.

Sartika, Ika, Ellis Endang Nikmawati, and Ai Mahmudatussa'adah. "Pengetahuan dan Keterampilan Pemilihan Makanan SehariHari Mahasiswa Program Studi Pendidikan Tata Busana." Media Pendidikan, Gizi dan Kuliner 3, no. 1 (2014): 65-76.

Scheid, Volked, Dan Bensky, Andrew Ellis, and Randall Barolet. Chinese Herbal Medicine Formulas \& Strategies. 2nd ed. Seattle: Eastland Press, 2009.

Siaputra, Hanjaya, Andini Emmiati, Evelyn Fajar Wibisono, Andita Widjaja, and Universitas Kristen Petra. "Pola Perilaku Sehat Pra Lansia dalam Mengkonsumsi Makanan Sehari-Hari di Maumere Studio." Jumal Hospitality dan Manajemen Jasa 3, no. 1 (2015): 131-40.

Sukadiyanto. "Peranan Latihan Olahraga terhadap Perkembangan Otak." Jurnal Cakrawala Pendidikan 23, no. 1 (2004): 99118.

Susilo, Adityo, Cleopas Martin Rumende, Ceva Wicaksono Pitoyo, Widayat Djoko Santoso, 
Mira Yulianti, Herikurniawan Herikurniawan, Robert Sinto, et al. "Coronavirus Disease 2019: Tinjauan Literatur Terkini." Jurnal Penyakit dalam Indonesia 7, no. 1 (2020): 45-67. https://doi.org/10.7454/jpdi.v7i1.415.

Thaib, Erwin Jusuf. "Al-Qur'an dan As-Sunnah Sebagai Sumber Inspirasi Etos Kerja Islami." Jurnal Dakwah Tabligh 15, no. 1 (2014): 1-9.

Wahyudi. "Empat Dimensi Kesehatan dalam Berpuasa.” Bimaispamekasan.net, 2020.

Wakhidah, Siwi Nur. "9 Penyebab Badan Lemas Tak Bertenaga, Sering Mengantuk dan Gemeteran.” wnw.merdeka.com, 2019.
Walakula, Ahmad Syarif. "Puasa Menurut Perspektif Biologi dalam Kajian Metabolisme Tubuh dan Hubungannya dengan Kesehatan.” IAIN Ambon, 2019.

Willy, Tjin. "Gangguan Pencernaan." Alodokter.com,

2019. https://www.alodokter.com/gangguanpencernaan.

Winchester, Daniel. "A Hunger for God: Embodied Metaphor as Cultural Cognition in Action." Social Forces 95, no. 2 (2016).

Yanggo, Huzaemah Tahido. "Makanan dan Minuman dalam Perspektif Hukum Islam." Tabkim 9, no. 2 (2013): 1-21.

Yuliana, Y. "Corona Virus Diseases (Covid-19): Sebuah Tinjauan Literatur." Wellness And Healthy Magazine 2, no. 1 (2020): 187-92. https://doi.org/10.30604/well.95212020. 